DOI: 10.17707/AgricultForest.61.4.08

\author{
Julia NIEDERMAYR*, \\ Erika QUENDLER, Thomas RESL ${ }^{1}$
}

\title{
FAMILY FARMING IN AUSTRIA - DEFINITION, CHARACTERISTICS AND DEVELOPMENTS
}

\begin{abstract}
SUMMARY
The ongoing discourse on agri-structural development in Austria and the EU as well as initiatives at a global scale have brought the phenomenon of family farming back into political and scientific discussions. Despite this recent interest, culminating in the United Nations' "2014 International Year of Family Farming", family farming is a system in which people live and work that has developed over centuries, fundamentally shaping the structure and policy of agriculture, not only in Austria. Yet, a generalised depiction of family farms is not applicable. They come in many shapes and sizes in terms of land size and capital, farm focus and the different types of farming. This contribution starts by discussing the overall concept of family farming. Then, the developments in Austria are outlined using select key agri-structural data along with certain characteristics of family farming such as employment, participation in agri-environmental measures as well as the social and cultural aspects of family farms. The results show that the majority of farms in Austria are family farms. They therefore play a key role in implementing agricultural policy and also have a high stake in ensuring a divers agricultural landscape and animal husbandry. However, they have undergone considerable restructuring processes in the last decades and will be challenged to develop competitive strategies and become more attractive for future generations.
\end{abstract}

Key words: Family farms, definition, structural evolution, Austria

\section{INTRODUCTION}

There are several reasons why the issue of the operational organisation of agricultural production and the debate about the future of "family farms" are so pertinent. These are (i) the discussion on the agro-structural goals in Austria and the European Union (EU) - e.g. on the subjects of farm size, land ownership or non-agricultural investors - as a requirement for legislation, legal practice and case law, (ii) the EU strategy "Europe 2020" dedicating a flagship initiative to small and medium enterprises (SMEs) in the economy, without referring to agriculture, agricultural policy or even family farms, (iii) the discussion about family farms is of global import (Böhme 2013). In Austria, the importance of

\footnotetext{
${ }^{1}$ Julia Niedermayr* (corresponding author: julia.niedermayr@awi.bmlfuw.gv.at), Erika Quendler, Thomas Resl, Federal Institute of Agricultural Economics, Vienna, AUSTRIA

Paper presented at the $6^{\text {th }}$ International Scientific Agricultural Symposium "AGROSYM 2015"

Note: The authors declare that they have no conflicts of interest. Authorship Form signed online.
} 
family farms as a core element of agriculture is undisputed. For decades, agricultural interest groups and decision makers have demonstrated a strong commitment to family farming as well as to sustainable agricultural and forestry production systems covering the whole territory and providing a high-quality food supply (BMLF 1969, BKA 2013). Nevertheless, changes in key framework conditions (e.g. open markets, production requirements, long-term nature of agricultural payments) and the ongoing structural changes have contributed to uncertainty amidst the farming population (Quendler 2011). Against this background, this paper frames the concept of "family farming" identifying the main criteria and characteristics which contribute to its definition. Subsequently select criteria are used to describe the status quo and development trends of Austrian family farms and their economic, ecological and social dimensions. Finally, future prospects for family farming in Austria are outlined. The following elaborations are based on previous work on family farming in Austria by Quendler (2015) and Partl and Quendler (2014).

\section{MATERIAL AND METHODS}

The general picture of family farms was refined using common definitions and characteristics found in literature in order to deduce descriptive criteria. The Austrian situation of family farms is presented accordingly. The agri-structural analysis of Austrian family farms is based on farm structure surveys (FSS) from 1980 to $2010^{2}$ provided by Statistik Austria (1980; 1995; 2010), which defines family farms according to the criteria 'legal status', i.e. farms belonging to a single natural person, operated as full- or part-time farms ${ }^{3}$ (Statistik Austria 2012). This definition is applied in the forthcoming analysis. The parameters outlined are the status quo and development of the number of farms, the average area per farm and labour force (in absolute and relative terms). This data is supplemented by income information from the Austrian Farm Accountancy Data (BMLFUW 2010a; 2011; 2012). In Austria, apart from agricultural and forestry income, off-farm income is collected from the participating farms thus allowing to depict the overall household income. Due to considerable annual fluctuations in farm income, a three-year-average was taken. Income figures are presented for small, medium sized and large farms, which have been derived from standard output size (SO) classifications. It has to be noted that Farm Accountancy Data selection criteria do not cover all agricultural holdings recorded in the farm structure survey; very small farms with SO $<8.000 €$ and very large farms with SO $>350.000 €$ are excluded. Participation of family farms in Austria's Agrienvironmental Programme ÖPUL is based on data from the Integrated

\footnotetext{
${ }^{2}$ Changed survey thresholds over time: 1980-1990: Farms with total farm size $>1$ ha; since 1990 incl. farms with no area; since 1995: farms with UAA $>1$ ha or $>3$ ha forestry area (Statistik Austria 2012)

${ }^{3}$ Off-farm working time of farm holder and spouse $<50 \%$ of total working time and minimum farm standard output (SO) of 8,000€=full-time farms; otherwise part-time farm (before 2010: SO: 6,000€) (Statistik Austria 2012)
} 
Administration and Control System (IACS) from 2010 (BMLFUW 2010b). Finally, their diversification strategies were identified through desk research and personal communication (pers. comm.) with relevant actors in the field and for the latest available data.

\section{RESULTS AND DISCUSSION}

The concept of family farming

A family farm manifests itself in a variety of shapes, depending on the natural, social and cultural as well as economic situation and the respective objectives of a farm (Garner, de la O Campos 2014). This makes the term difficult to grasp. The FAO established the following definition: "Family Farming (also Family Agriculture) is a means of organising agricultural, forestry, fisheries, pastoral and aquaculture production which is managed and operated by a family and predominantly reliant on family labour, both women's and men's. The family and the farm are linked, coevolve and combine economic, environmental, reproductive, social and cultural functions.” (Garner, de la O Campos 2014). However, the authors argue that rather than a one-size-fits-all definition, a conceptual outline of the term should be established. In table 1 , family farms are characterised according to five criteria: labour force, type of tenure, decision making, employment basis and family unit.

Table 1. Criteria and characteristics defining family farms

\begin{tabular}{|l|l|}
\hline Criteria & Characteristics \\
\hline Labour force & $\begin{array}{l}\text { On-farm work occurs mainly by the farm holder, the spouse and } \\
\text { other family labour; temporary employment of non-family labour }\end{array}$ \\
\hline Type of tenure & $\begin{array}{l}\text { Agricultural land and other farm land are farmer owned; renting } \\
\text { of additional land is common; yet, sole tenant farming is not } \\
\text { excluded; rented or leased equipment and/or labour is common }\end{array}$ \\
\hline $\begin{array}{l}\text { Decision- } \\
\text { making }\end{array}$ & $\begin{array}{l}\text { By the family; farm holders and/or family members take all } \\
\text { necessary farm related decisions }\end{array}$ \\
\hline $\begin{array}{l}\text { Employment } \\
\text { basis }\end{array}$ & $\begin{array}{l}\text { Farm income does not necessary need to fully sustain the } \\
\text { family/household; non-farm income may ensure the survival of } \\
\text { even relatively small farms; questions of liability or social } \\
\text { insurance requirements lead to “new” organisational forms (e.g. } \\
\text { farm cooperation, diversification of household income) }\end{array}$ \\
\hline Family unit & $\begin{array}{l}\text { The holding and the family constitutes a unit; a family farm is } \\
\text { both working and living place at the same time; the farm is passed } \\
\text { on from generation to generation, family members are usually } \\
\text { closely related; in most cases the family farm is a natural person; } \\
\text { alternative family farm-models are on the rise (e.g. patch work } \\
\text { families, multi-family farms, group holdings) }\end{array}$ \\
\hline
\end{tabular}

Source: Quendler 2015 according to Böhme 2013; Priebe 1942 in Lipinsky 1988; Urff 1983; Planck, Ziche 1979; EEC-Commission 1983; Bubendorf, Gantner 1990; Hill 1993 in Garner, de la o Campos 2014; Djurfeldt 1996 in Garner, de la o Campos; Iwamoto 2006 in Garner, de la o Campos; Kirner 2010; Schweizer Bauernverband 2013. 
Beside the family farms as described therein, other forms of family operated farms and holdings are on the rise and will become ever more significant in future. These are multi-family run farms, agricultural family holdings or "agricultural family holding companies" or "sowing pools" of legal status (group holdings, legal persons) other than natural persons with a higher percentage of non-family labour force (Böhme 2013; IAMO 2013). With these aspects in mind, the forthcoming representation of family farms can be treated only approximately, since it is limited to the legal form. Nevertheless, trends do become visible.

Agri-structural development of Austrian family farms

In 2010, 92.7\% $(160,697)$ of all agricultural and forestry farms are family farms, of which $41.6 \%(66,802)$ are operated full- and $58.4 \%$ part-time $(93,895)$. Only $3.2 \%(5,570)$ of farms are operated by group holdings and $4.1 \%(7,050)$ by legal entities. Family farms cultivate $86 \%$ of the total utilised agricultural area and $60.5 \%$ of the total farm area, where full-time farms hold a higher average total farm area (43.2 ha) than part-time farms (16.7 ha). $4.8 \%$ of the total farm area is operated by group holdings with a higher average total farm area of 62.9 ha. Legal entities hold 362.1 ha and $34.7 \%$ of the total farm area.

From 1980 to 2010), the number of family farms belonging to a single natural person has almost halved (by $-48 \%$ or 147,960 farms), with the rates of change being similar for full- and part-time farms (-50\%;-46\%). In contrast, other legal farm types show an increase in number of farms from 10,428 to 12,620 (+21\%). This is mainly due to an increase of group holdings (companies under civil law) as per the 2007 FSS and can be attributed to a shift from full-and part time farms to group holdings (pers. comm., Ms. Dötzl, Statistik Austria 2014). Thus, strong restructuring processes at socio-economic farm type level have occurred over the observed time span. This also applies to average farm sizes. Out of all farms, the average total farm area came to 24.8 ha in 1980 and increased up to 42.4 ha in 2010. When looking at the legal form of the holdings, a different picture appears. Average farm sizes have increased for both family farm types over the past 30 years coming to 43.2 ha per farm for full-time farms (+16.2 ha) and a comparatively low 16.7 ha for part-time farms (+8 ha). Interestingly, the average farm size of group holdings went down considerably from 292.1 ha in 1999 (which was the first time they were considered in FSS) to 62.9 ha, which can be explained by a notable increase in the number of farms with low land area (pers. comm, Ms. Dötzl, Statistik Austria 2014).

A downward trend has also been observed in family labour force, 232,296 people have left employment in agriculture and forestry since 1995 (-40\% or an average of 15,486 persons per year up to 2010). In 2010, the proportion of family to non-family labour force was considerably higher providing the majority of the labour input (90\% in 2010). Yet, since 1995 (95\% family labour force) there has been a shift towards non-family labour force, which is mostly the case for fulltime farms $(+47 \%$ or 578 persons per year); in contrast, part-time farms saw a reduction of external labour (-16\% or an average of -114 persons per year). 
Economic, ecological and social dimension of family farming

Family farms pursue different income generating strategies according to their economic farm size. Figure 1 shows how the share of agricultural and forestry (A\&F) income with respect to total earned income ${ }^{4}$ increases with increasing farm size. Thereby, small-sized family farms (22\% of farms sampled) derive a considerable amount of their earned income off-farm. Medium and large farms (53\% / 25\% of farms sampled) derive their income predominantly from non-agricultural income. Average unpaid labour units increase with farm size and so does the income from $A \& F$ per unpaid labour unit.

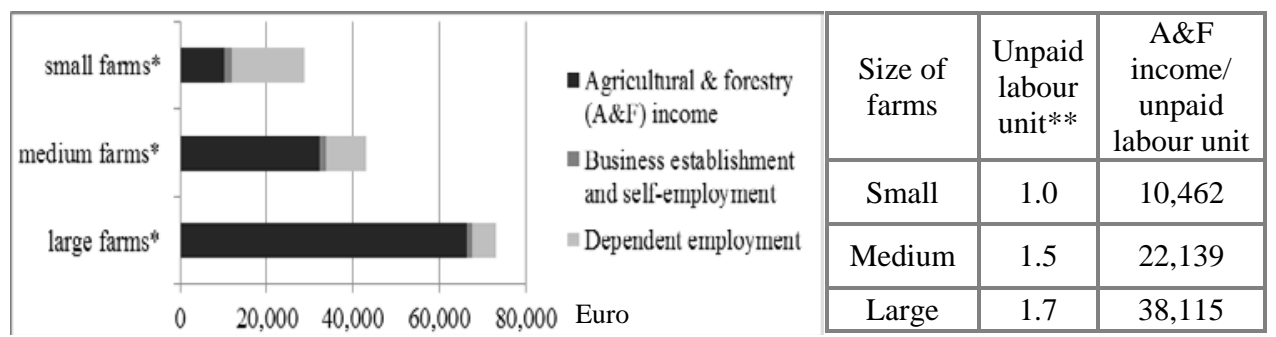

*Farm size: small 8,000 < 30,000 SO, medium 30,000 < 100,000 SO, large 100,000 < 350,000 SO; $\mathrm{SO}=$ standard output. ${ }^{* *}$ One person working a minimum of 270 days per year and 8 hours per day

Figure 1. Average income from agriculture and forestry (A\&F) and off-farm income in Euro per farm by economic size and unpaid labour unit, 3-year average 2010-2012 (own elaboration according to BMLFUW 2010a; 2011; 2012).

Family farms also undertake a wide range of diversification activities which may have an economic importance for the farms themselves but also fulfil social and cultural functions. There are several farm diversification initiatives opening family farms to a broader social environment such as (i) "Holidays on the farm" with 2,650 participating family farms in the homonymous association and one tourist bed in every seven on a family farm in Austria in 2012 (BMLFUW 2012b), (ii) social farming initiatives e.g. "school on the farm" (460 farms and 78,417 attending pupils/trainees in 2011/2012; pers. comm. Mrs. Kaufmann, BMLFUW, 2014) and "green care" ( 570 family farms providing care, education or social work services; Wiesinger et al. 2013) or (iii) direct marketing activities, where 46,000 or $\sim 1 / 3$ of all family farms market their products by e.g. farm gate sale, farmers markets or in cooperation with gastronomy (KeyQuest 2010).

Thus it seems as if family farms have developed different strategies to encounter structural change. The challenge will be to find the appropriate mix of managerial strategies, grasp current opportunities and enable adaptability and transformability in order to ensure the resilience of family farms in future (Darnhofer 2009).

\footnotetext{
${ }^{4}$ Earned income: income from A\&F plus off-farm income, i.e. from business establishment, selfand dependent employment.
} 
Family farms do also play a major role in the Austrian environmental programme ÖPUL (second pillar of the Common Agricultural Policy), since they hold $95 \%$ of the area-related measures and $98 \%$ of livestock-related measures. Also, family farms hold $94 \%$ of 450,000 ha under organic cultivation (BMLFUW 2010b). These figures suggest that family farms have a high stake in securing a diverse agricultural landscape and animal husbandry.

\section{CONCLUSIONS}

The majority of farms in Austria are family farms. They make a significant contribution when it comes to the implementation of the Common Agricultural Policy and in guaranteeing sustainable agriculture in Austria. However, family farms underwent massive agri-structural developments in the past years and farm abandonment has not slowed down. Family farms will need to develop competitive strategies to create a sustainable environment and become more attractive for future generations. Due to the increasing specialisation and division of labour, family farms are increasingly likely to adopt other organisational forms, e.g. legal persons, group holdings, "agricultural holdings companies" or "sowing pools", in order to address liability or social security issues. It seems remarkable that - despite modern production methods and organisational forms of agriculture - family farms have continued to thrive.

\section{REFERENCES}

BKA - Federal Chancellery (2013). Arbeitsprogramm der österreichischen Bundesregierung 2013-2018 [Working programme of the Austrian federal government 2013-2018]. https://www.bka.gv.at/DocView.axd?CobId=53264 [21.08.2014].

BMLFUW - Federal Ministry of Agriculture, Forestry, Environment and Water Management (2010a; 2011; 2012). Grüner Bericht 2010, 2011, 2012. Vienna. [Annual agricultural reports].

BMLFUW - Federal Ministry of Agriculture, Forestry, Environment and Water Management (2010b). Integrated administration and control system data 2010. Vienna.

BMLF - Federal Ministry of Agriculture and Forestry (1969). Landwirtschaft im Wandel. Agrarstrukturpolitik in Österreich, BMLF, Vienna. [Agricultural structural policy in Austria].

Böhme, K. (2013). Familienbetrieb-Renaissance einer Betriebsform? Briefe zum Agarrecht (BzAR), 10, 405-413. [The renaissance of Family Farms?].

Bubendorf, A., Gantner, U. (1990). Zur dauerhaften Existenz von bäuerlichen Familienbetrieben. Landwirtschaft Schweiz, Band 3, 401 - 403. [Long term survival Family Farms in Switzerland].

Darnhofer, I. (2009). Strategies of Family Farms to strengthen their resilience. 8th International Conference of the European Society for Ecological Economics, June 2009, Ljubljana.

EEC-Commission (Hrsg.). (1983). Familienbetrieb kann auch 400 ha haben. AgraEurope, 11, Kurzmeldungen. [Family Farms may also hold 400 ha]. 
Garner, E., de la O Campos, A.P. (2014). Identifying the "family farm": an informal discussion of the concepts and definitions. ESA Working Paper No. 14-10, FAO, Rome.

IAMO - Leibnitz Institut for Agricultural Development in Transition Economies (2013). Pressemitteilung vom 18.9.2013, Halle. [Press release from 18.9.2013].

KeyQuest (2010). Direktvermarktung Marktforschungsstudie im Auftrag von Agrar Projekt Verein, KeyQuest GmbH Marktforschung Garsten, Austria. [Direct marketing survey in Austria].

Kirner, L. (2010). Abstract DI Dr. Leopold Kirner. Veranstaltung: Idealbild mit Zukunft? Ökosoziale Agrarpolitik im Gespräch - Stichwort bäuerlicher Familienbetrieb, Donnerstag, 18. Juni 2009. [Venue: Eco-social agricultural policy under discussion $\quad-\quad$ Keyword: $\quad$ Family Farms] http://www.oekosozial.at/uploads/pics/Abstract\%20Kirner_end.pdf [19.8.2014].

Landesverband für Urlaub am Bauernhof (2012). Urlaub am Bauernhof - Tradition innovativ vermarktet. http://www.urlaubambauernhof.at/index.php?id=9339 [01.7.2015].

Lipinsky, E. (1988). Der bäuerliche Familienbetrieb - Sein Wesen und seine Rechtsstellung aus deutscher Sicht. Agrarrecht 19, Heft 2, Beil. I, 1-5. [Legal status of Family Farms in Germany].

Partl, A.-M., Quendler, E. (2014). Zur Abgrenzung, Charakterisierung und Funktionalisierung Bäuerlicher Familienbetriebe in Österreich. Land\&Raum 3/2014. [Characteristics and Functions of Family Farms in Austria]

Planck, U., Ziche, J. (1979). Land- und Agrarsoziologie. Eugen Ulmer Verlag, Stuttgart. [Rural and agricultural sociology].

Quendler, E. (2015). Zum Phänomen bäuerlicher Familienbetriebe - Charakteristika und Entwicklungen. In: Egartner, S. and Resl, T. (eds): Einblicke in Österreichs Landwirtschaft seit dem EU-Beitritt. Schriftenreihe Nr. 108, Federal Institute of Agricultural Economics, Vienna. [The phenomenon of family farming characteristics and developments]

Quendler, E. (2011). Junge Landwirtschaft mit Zukunft. Schriftenreihe Nr. 101, Federal Institute of Agricultural Economics, Vienna. [Perspectives for a "young" agriculture].

Schweizer Bauernverband (2013). Situationsbericht 2013. Erfolgsmodell: der bäuerliche Familienbetrieb. Brugg. [Situation report 2013: Success model Family Farms].

Statistik Austria 2012. Agrarstrukturerhebung 2010. Bericht 1.17. Vienna. [Farm Structure Survey].

Statistik Austria 1980; 1995; 2010. Farm Structure Survey data 1980, 1995, 2010, Vienna.

Urff, W. von (1983). Landwirtschaftliche Familienbetriebe und ihre Existenzsicherung. Schriftenreihe für ländliche Sozialfragen, Heft 90. [Family Farms - ensuring long term survival].

Wiesinger, G., Quendler, E., Hoffmann, C., Di Martino, A, Egartner, S., Weber, N., Hambrusch, J. (2013). Soziale Landwirtschaft. Situation und Potentiale einer Form der Diversifizierung land- und forstwirtschaftlicher Betriebe in Österreich, Südtirol und Trentino. Federal Institute for Mountainous and Less-Favoured Areas, Vienna. [Social farming-status quo \& potential in Austria, South Tyrol Trentino]. 